\title{
Grammaticalization of Progressive Aspect in a Slavic Dialect in Albania
}

\author{
Maxim Makartsev \\ wissenschaflticher Mitarbeiter, Institut für Slavistik, Fakultät III - Sprach- \\ und Kulturwissenschaften, Carl von Ossietzky Universität, Oldenburg, \\ Germany / senior research fellow, Institute for Slavic Studies, Russian \\ Academy of Sciences, Moscow, Russia \\ maxim.makartsev@uni-oldenburg.de
}

\begin{abstract}
The article focuses on two markers of progressive aspect that are emerging in a Balkan Slavic dialect in Albania, presumably under Albanian influence. One of them dates back to locative ( $g$ e 'where'). Two processes intertwine on the grammaticalisation path of the other (toko): originally an adversative conjunction ('but'), it was structurally mapped to its polysemic (adversative, but also affirmative, progressive, conditional) Albanian counterpart po. At the same time, its choice to mark progressive was additionally motivated by the phonetic similarity with another Albanian progressive marker duke. In the first third of the $2 \mathrm{o}^{\text {th }}$ century both markers were used as synonyms. However, during the subsequent process of language attrition the language community in question split into three groups regarding the use of the markers: of the last six remaining speakers one speaker used only ǵe as an optional marker; one speaker used toko as an optional marker; four other speakers used toko as a regular progressive marker.
\end{abstract}

\section{Keywords}

progressive aspect - Balkan Slavic dialects - language attrition - frog stories 


\section{Introduction}

The dialect under scrutiny, the last remnant of the broad zone of Slavic dialects that were once spread throughout Epirus from Lake Ohrid and the Pindus Mountains to the Adriatic and Ionian Sea coasts (see Seliščev, 1981/1931), is spoken in Boboshtica and Drenova in Korça district. It is a dialect island, located in the Korça plain (about $85^{\circ}$ meters above sea level) to the south of the town of Korça. It is separated from the closest Prespa Macedonian dialects by the mountain chain of Mali i Thatë or Galičica (the lowest mountain pass of Zvezda is about $1100 \mathrm{~m}$ high), from Ohrid-Prespa dialects by a hill chain between Korça valley and Lake Ohrid (about $5^{0} \mathrm{~km}$ distance from Boboshtica to Tushemisht with a 300 meter drop at the northern slope of the hill chain), and from Vërnik (an Aegean Macedonian village within the territory of Albania where a structurally similar dialect is spoken) by the mountain chain of Morava (around $30 \mathrm{~km}$ long and $10 \mathrm{~km}$ wide) the wide Devoll valley and a chain of hills that complicate the access to Vërnik even nowadays. There are many Slavic toponyms in Korça valley that are evidence of a previous Slavic-speaking population (Ibid.); however, at least for several generations, Boboshtica and Drenova have been the only villages in the vicinity with Slavic speakers (see Map 1).

A full description of the dialect of Boboshtica and Drenova was given in 1936 by André Mazon (Mazon, 1936, also Mazon and Bajrova, 1965; Steinke and Ylli, 2007, gave a grammatical overview of the dialect as of the end of the $20^{\text {th }}$ century). Božidar Vidoeski (1997) includes it into the South-Eastern dialectal group (narečje) of Macedonian (even though in geographical terms it should be considered as the most South-Western Macedonian dialect) and underlines that it has more common features with Kastoria and other Aegean Macedonian dialects (South-Eastern) than with Prespa and Ohrid-Struga dialects (Western Macedonian). The autonym for the dialect is Kajnas (in the dialect, kaj nas 'like us' $)$.

Since 1936, the number of Kajnas speakers has decreased drastically, both in absolute numbers and in percent, as a result of language shift (the majority of families in the villages switched to Albanian at least two or three generations ago), of huge migration to Albanian cities and abroad, and of Aromanians settling in the villages. During my research in Boboshtica and Korça (since 2010), six speakers of the dialect could be found, three of whom were fluent enough to produce narratives and to conduct dialogues in the dialect. I could not find any Slavic speakers in Drenova. The data from Drenova for this article were

1 If not specified the translation in the article is mine. 


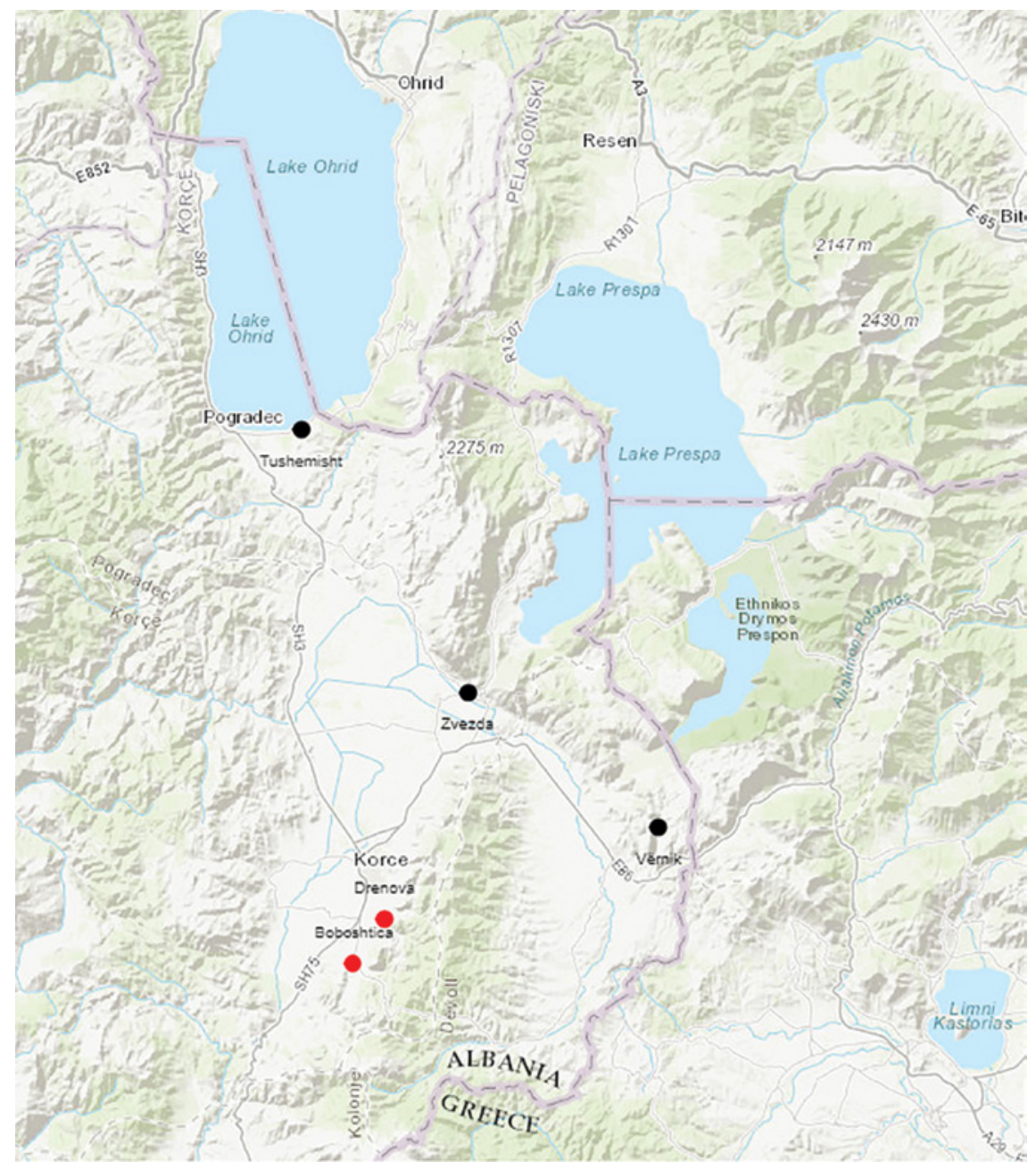

MAP $1 \quad$ Boboshtica and Drenova

recorded with three further speakers (probably the last ones) who had moved to the town of Korça (around $5 \mathrm{~km}$ from Drenova) and now live there. All of the recorded speakers are Albanian-Slavic bilinguals with Albanian as first language and different (but always limited) fluency in Slavic. ${ }^{2}$ The speakers are listed at the end of the article.

2 Cf. an open list of signs of limited fluency: "halting, hesitating speech patterns, difficulties in offering a translation of a simple sentence, inability to provide a coherent narration, gaps in vocabulary that designates items of material cultural and natural environment and other everyday objects, grammatical simplifications by comparison to the language as spoken by 
As a variety under intense contact, Kajnas demonstrates various types of code-switching. In normal settings, no speaker seems to ever conduct a conversation from the beginning to the end continuously in Kajnas. The speakers can, however, produce long texts in Kajnas if the situation requires it (for example when they are asked to do so). ${ }^{3}$ These narratives have a number of examples of intrasentential code-switching, as a result of which hybrid Albanian-Kajnas elements and constructions emerge. Here the difference is important between "mixed discourse" and "mixed speech" (gemischter Diskurs vs. gemischte Rede), proposed by Gerd Hentschel and Jan Patrick Zeller (2013).

In fact, after the death of the last monolingual speakers and critical shrinkage of the community, Kajnas today exists only through mixed speech, highly contaminated with Albanian, with a variety of hybrid ${ }^{4}$ forms and congruent lexicalizations. A certain gap exists between the way the dialect is attested in the descriptions and texts published by André Mazon (1936) and Maria Filipova-Bajrova (Mazon and Bajrova, 1965, on data from the 1930s), and in

fully fluent speakers, clear evidence of interference from a dominant language" (Thomason, 2015: 54) - the recorded speakers show all of the listed signs of limited fluency to various extents.

3 It is important to add that the interviews I conducted when I insisted that the speakers talk to me only in Kajnas were to a large extent unnatural settings for them to speak their language (even though in some cases it is possible to treat it as a sue generis practice: talking to outsider researchers as an oral genre, cf. Makartsev, 2017). Paradoxically, during my work in the community at the early stage (in 2010 and 2011) my insufficient knowledge of Albanian at the time was an advantage, because Kajnas inevitably had to be the only means of communication between me and the interlocutors.

4 Gerd Hentschel and Jan Patrick Zeller characterize "hybrid" forms as those combining two specific morphemes from both contacting languages (Hentschel and Zeller, 2013: 132). In their case the languages in contact are structurally and genetically close, namely Russian and Belarusian, so the researchers have to pay specific attention to the frequent cases when a word includes morphemes "common" ("gemeinsam") to both languages. If there is no close genetic relationship, which is the case of Albanian and Kajnas, the number of "common" morphemes is very small. However, structural similarity (both languages belong to the Balkan sprachbund) and higher degree of analytism make it easier to produce "hybrid" Albanian-Kajnas forms and sentences (see Clyne, 2003; Muysken, 2013 for typological distance between languages and its impact on the language contact). The hybridity of this kind in Balkan languages is still waiting a proper complex approach, even though there is already a lot of research on different language pairs, that investigate various types of bilingualism and hybrid forms. See e.g., Brown and Joseph, 2015, with an attempt to provide a classification of hybrids on different levels of analysis in Greek varieties in Southern Albania, taking into account also mixing at the level of phonological realization of several phenomena. Sobolev (2018) provides an outline of a "simultaneous comprehensive interplay of Slavic, Albanian and Balkan Romance, pan-Balkan and hybrid phenomena" in a Golo Bordo dialect of Macedonian spoken in Eastern Albania. See also the section on "Toko between Albanian duke and $p o$ " for more examples of Albanian-Kajnas hybrid forms. 
those published by Klaus Steinke and Xhelal Ylli (2007). The former describes a full-living dialect in the situation of bilingualism, the latter presents a dying dialect no longer in active use. The former is a collection of texts of various styles covering a broad time period: a sermon from 1874, Gospel translations from 1870s-188os; tales and songs recorded with informants of different ages (born mostly around 1850s-1880s), letters written in 1931-1934, thus representing different apparent and real time stages of the development of the dialect. The latter is mostly a collection of narratives (primarily memorates) of two speakers. This means that the difference we find between the texts published in Mazon (1936) and Mazon and Bajrova (1965) and the texts and transcripts published in Steinke and Ylli (2007) reflect not only the changes in language use (the shrinkage of the language community and the inevitable changes in language variation, cf. Palosaari and Campbell, 2011: 112 passim), but also belong to specific (and different) styles, thus adding constraints to forms that can or cannot be attested in the data.

\section{Progressive aspect in Slavic and in Albanian}

This paper is specifically concerned with one case of structural transfer from Albanian into Kajnas, namely, how progressive aspect has been grammaticalized in the latter dialect. In the majority of Slavic languages and dialects a special form for progressive or continuous aspect ${ }^{5}$ is not attested. It is definitely outside of what can be called 'Standard Average Slavic'. Its domain, in English covered by present progressive forms (Joan is singing well - Quirk et al., 1989: 197), in Slavic is usually expressed by verbs in present tense, imperfective aspect, and does not require any specific marking. ${ }^{6}$ This is the situation in the

5 "Progressive views an action as ongoing at reference time" (Bybee et al., 1994: 126). There has been a discussion on the place of progressive aspect in the system of aspectual oppositions in the world's languages, especially on the connection between progressive and continuous aspects (initiated by Comrie, 1998/1976): "while progressive is usually reserved for dynamic verbs and predicates, non-progressive continuous aspectuality additionally covers stative predicates" (Mair, 2012: 806). Typologically it is problematic to separate continuous from progressive (see the criticism in Bybee et al., 1994: 137-139); however continuous is usually kept as a separate term for the languages that have separate forms for progressive and continuous aspects (Mair, 2012: 807).

6 Cf. what the Academic Grammar of Russian language calls nastojaščee actual'noe "actual present" (Švedova, 1980: 628, where it is defined as "konkretnoe nastojaščee vremja momenta reči", or "concrete present tense of the moment of speech"), which is basically the use of verbs of imperfective aspect in present tense ("konkretnoprocessnyj tip upotreblenija", or "concrete-processual type of use"). 
majority of Slavic languages and dialects. Under the influence from other languages, special constructions marked for this type of meaning can emerge, which was the situation e.g., in Slovincian bäc vu lovjińá 'to be fishing'. Forms like these are considered structural borrowings from Low German; cf. ick weer bit schriben, as he keem 'I was writing when he came' (Piotrowski, 1981: $40-41)^{7}$

Albanian, the dominant language with which Kajnas speakers have been bilingual for at least several generations, ${ }^{8}$ has two kinds of forms for expressing actions ongoing at reference time. ${ }^{9}$

The first way is the particle $p o+$ Present:

(1a) Ata po këndo-jnë
they Prog sing-Prs.3PL
'They are singing.'

Compare it with (1a) for non-actual present.

$\begin{array}{lll}\text { (1b) Ata këndo-jnë } & \text { mirë } \\ \text { they sing-Prs.3PL } & \text { good } \\ \text { 'They sing well.' } & \end{array}$

Newmark et al. (1982: 36) interpret forms like those in (1a) in the following manner: "a momentary action in progress". Buchholz and Fiedler define the meaning of forms with $p o$ as "Fixierung, die Festlegung einer Handlung auf einen bestimmten Zeitpunkt oder parallel zu einer anderen Handlung" [fixation, a definition of an action at a certain time or in parallel to another action]. They are used in various situations, among them: a) "Gleichzeitigkeit mit dem Redemoment" [simultaneity with the speech moment]; b) "Koinzidenz von Handlung und Äußerung" (coincidence of the action and the statement); c) "Im Prs historicum signalisiert $p o$ + Prs Gleichzeitigkeit von Handlung und Erzählzeit" [in historical present po + present signals the simultaneity of the action and the narration time] (Buchholz and Fiedler, 1987: 168).

7 I am grateful to Motoki Nomachi, who drew my attention to these Slovincian data.

8 Judging from the abundance of Albanian lexical borrowings and switches in the texts of the tales and letters published by Mazon.

9 Differences between Standard Albanian and Korça dialect in this respect are irrelevant, as Korça dialect uses both forms of progressive, see ADGJSh: 391 (map 320, question 131). 
The semantics of $p o$ (notwithstanding the progressive forms) in Albanian is quite broad. Joseph gives the following brief outline of the meanings that $p o$ can have.
a) Particle:
- affirmative particle 'yes'
- confirmative tag in questions: 'is that right?'
- confirmative identifier: 'exactly; precisely; the very'
- indicator of momentaneous (on-going) activity: 'be VERB-ing'
b) Interjection:
- 'oh say!' 'Say!' 'But say!'
c) Conjunction:
- 'but'
- in conditional clauses: 'if; if only' (Joseph, 2011: 29-30).

For the description of Kajnas data, two meanings of Albanian po are relevant: indicator of momentaneous activity, or progressive; and that of conjunction 'but', or adversative meaning. In Albanian, these can be differentiated structurally: adversative $p o$ operates on the whole clause, while progressive $p o$ has only a verb form (not a VP) in its scope. Progressive $p o$ and the verb are inseparable, and there can be only clitics between them (negation marker $s^{\prime}$ or nuk is attached before $p o$ ).

The etymology of po in Albanian is not very clear. In his recent article, Joseph (2011) attempted to shed some light on this problem. It seems that in Albanian adversative and progressive $p o$ have different etymologies. Adversative $p o$ is probably a variant of por 'but', which in its turn is a borrowing from Latin porrō 'then; moreover, but' (Orel, 1998: 337). Progressive po, however, is a semantic development of affirmative $p o$.

[...] affirmative po is from an original asseverative marker * $p \bar{s} s t$ (via the regular loss of a word-final consonant cluster and the regular development of Indo-European * $\bar{e}$ into Albanian $o$ ), which itself derives from PIE *pe (as in Latin quippe (< *quid-pe) 'why so?; of course') combined with *est, an apparent $3 \mathrm{SG}$ injunctive mood form of 'be'. Literally, therefore, in this account affirmative po was originally "it is thus" (or the like). (Joseph, 2011: 32, quoting a private conversation with Eric Hamp)

The second way to express progressivity in Albanian is the marker duke + participle. 


$\begin{array}{lll}\text { (2a) Jam } & \text { duke } & \text { vrap-uar } \\ \text { be.Prs.1SG } & \text { Prog } & \text { run-PтсP } \\ \text { 'I am running.' } & & \end{array}$

The complex verbal form in (2a) is basically an adverbialized participle (adverbial marker ${ }^{10} d u k e+$ participle form) that is then attached to the verb 'to be', thus becoming finite. Its structure is highlighted in an ad hoc word-by-word translation of this example by IK into Kajnas. ${ }^{11}$
(2b) Esa
tarčeničḱkim.
be.Prs.1SG
run-ADVPTCP
'I am running.'

Newmark et al. (1982:36) describe forms like (2a) as "an action already in progress". Probably this is echoed in Buchholz and Fiedler's grammar of Albanian that explains forms like (2a) through the semantics of a gerund. They state that the semantics of these forms is narrower than that of po forms ("Gleichsetzung", or "equating" rather than "Fixierung", or "fixation"; Ibid.: 169). Duke forms can be substituted by po forms, but the opposite is not always possible. This difference as a sequence imposes certain limitations on duke forms: their use is defined by the cognitive load the speaker has when speaking about simultaneous actions that must have a single reference point (Matras, 2009: 151). At the same time, $p o$ forms as "momentary action in progress", allow for changing reference. For example, when commenting on a video stream with various successive actions on the screen, the use of duke forms would be very unlikely, as they are expected to be grounded within a certain time reference. At the same time, the moment of speech in fact offers a moving reference frame within which any number of $p o$ forms can be pinned. In other words, progressive $p o$ is used for foreground actions, while duke forms are used for background actions (which is underlined by the semantics of the gerund).

Another possible way to explain the difference between $p o$ and duke is to apply the opposition between continuous and progressive aspect.

\footnotetext{
10 Or grammatical particle.

11 Since this is the only account of this form (in my interviews with IK, in Steinke and Ylli's interviews with the same informant, and in the whole corpus of texts and transcripts that exist for Kajnas), this form has to be considered an ad hoc structural borrowing from Albanian. In Kajnas the stress is usually penultimate, so I mark it only if it has different position.
} 
Po is applicable both to actions and to states, which makes it explainable as nonhabitual imperfective (that is, continuous aspectual form, following Comrie (1998/1976:25), while duke is hardly if at all applicable to states, cf. (3) vs. (4):

(3) Unë nuk po kupto-j se çfarë po ngje-t I Neg Prog understand-Prs.1Sg Comp what Prog happen-Prs.3Sg 'I don't understand what's going on.' (ANC [Albanian National Corpus]: Beqir Musliu, “Mezaria”, 1976)

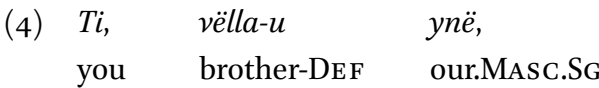

si duke- $t \quad$ ende nuk je duke kuptuar as seem-Prs.3SG.Refl in_the_end Neg be.PrS.2Sg Prog understand-PtcP se çfarë gjë-je madhështor-e ka ndodh-ur that what thing-ABL.INDEF magnificent-Fem have.PRs.3SG happen- РтcP

$n \ddot{e}$ hapësir-ën $\quad$ Albëri-së.

in space-Def.Fem.Acc Agr Albëria-Def.Fem.Gen

'You, our brother, still seem to not have understood what a magnificent thing happened in the terrain of Albëria.' (ANC: Adem Demaçi, “Alb Prometeu", 2008)

The Albanian National Corpus (2011 - to date, current number of words around 20 mil - Morozova et al., 2016; ANC) gives 63 entries in 48 documents for kuptoj in the scope of $p o$ for various styles (as in 3), while kuptoj in the scope of duke is attested only three times (twice in one novel - example 4) and is hardly, if at all, used in Standard Colloquial Albanian. (The three entries in question come from highly stylized historical prose.) Thus po forms seem to be interpretable rather as continuous, and duke as progressive sensu stricto. However, it still has to be researched if this holds for other actions and states in Albanian. For the purpose of this article the term progressive (in the broad sense) will be used for both po and duke forms.

The etymology of the Albanian duke raises several questions. However, the most acceptable etymology seems to be from PIE *tu kūōd 'da wo.'12 In other

12 "Die Partikel tuke (im Neualbanischen mit Schwachton duke) ist eine Zusammensetzung aus den Partikeln $t u+k e(<* t u+k u \bar{c} d)$ "da wo", eine ursprüngliche Temporalkonjunktion" [The particle tuke (with weak tone in Modern Albanian), is a composition of the particles $t u+k e\left(<{ }^{*} t u+k u \bar{o} d\right)$ "where", an original temporal conjunction], Matzinger, 2006: 136). 
words, this progressive marker dates back to a locative marker, a situation typologically spread in the world languages (Mair, 2012; Bybee et al., 1994: 128 passim). In Albanian, progressive can also mark actions in the past. It is a transposition of present progressive forms ( $p o+$ imperfect; 'to be' in the past + duke + participle).

It is important to add that progressive in Albanian seems to be among the so-called anti-Balkanisms, "linguistic phenomena and operations that in the situation of linguistic contact between Balkan languages do not go through the boundaries of their language, utmostly antidonational phenomena and operations, whose borrowing and calquing in other languages is maximally difficult" (Sobolev, 2011: 186-187 ${ }^{13}$ ). As Joseph puts it regarding $p o$,

this Albanian element is unique among the Balkan languages. That is, no other language shows a (more or less) free preverbal form that marks aspect and specifically a type of imperfectivity (in the sense of signaling an on-going event), that is, progressivity. (Joseph, 2011: 29)

At the same time, Joseph adds, even though the opposition between progressive and non-progressive does not exist in other Balkan languages, its emergence in Albanian might be supported by existence of aspectual oppositions in Balkan languages (cf. Slavic aspect, especially in Macedonian with broad secondary imperfectivization, but also in Greek with the opposition of perfective vs. imperfective).

The specific sociolinguistic situation within which the Boboshtica-Drenova dialect exists (long-term bilingualism with Albanian, language community consisting only of heritage speakers) potentially makes borrowing of grammar easier (cf. O'Shanessy, 2011). My attention was drawn to present progressive in Kajnas when I was working with $\mathrm{IK}^{14}$ on a questionnaire aiming at describing its verbal morphology. While translating sentence (1a) into Kajnas, where I was interested by the $3^{\text {rd }}$ person plural of the verb 'to sing', IK used the following form. ${ }^{15}$

I want to express my gratitude to Marek Majer for the consultation and the chance to discuss this etymology.

13 Even though Albanian progressive in his publication is not included in the preliminary list of anti-Balkanisms.

14 See the list of speakers at the end of the article. The use of ge for progressive marking in the dialect on a limited set of spoken data was briefly commented on in Makartsev (2013a, 2013b).

15 I keep the supposed Kajnas progressive markers without a special grammatical notation, as it is exactly their grammatical nature that is in the scope of this article. Ge will be notated as 'where' only in locative meaning, elsewere it will be kept in the grammatical 
(5) Tija ǵe pj-ă sega they ǴE sing-Prs.3PL now 'They are singing now.'

When I asked what ǵe in (5) meant he answered.

(6) Toz "ǵe" esti "po". "Po" to albanska esti this ǴE is.Prs.3Sg Prog Prog that Albanian is.Prs.3Sg

"ǵe", "ǵe pj-ă". "Tija ǵe jed-e ljep".

ǴE ǴE sing-Prs.3PL they ǴE eat-Prs.3PL bread

"Tija ǵe pj-ă”. "Tija ǵe tarč-e”. [...] "Tashi po they ǴE eat-Prs.3PL they ǴE run-Prs.3PL now Prog

pi raki". "Sega ǵe pij-am rakija".

drink.Prs.1SG rakia now ǴE drink-Prs.1SG rakia

"Po gjëmo-n" - "Ǵe garm-i".

Prog thunder-Prs.3Sg ǴE thunder-Prs.3Sg

$\begin{array}{lll}\text { Sega } & \text { ǵe } & \text { garm- } i . \\ \text { now } & \text { ǴE } & \text { thunder-PRs.3SG }\end{array}$

"This ǵe is po. Po in Albanian is ǵe, "they are singing". "They are eating bread". "They are singing". "They are running". [Albanian:] "Now I am drinking rakia." [Kajnas:] "Now I am drinking rakia." [Albanian:] "It is thundering" [Kajnas:] "It is thundering”. It is thundering now.'

This marker was used in another translation task.

(7a) Albanian (stimulus)

Tani po push-on, por pas ca minut-ash now Prog relax-Prs. 3 Sg but after several minute-AbL.Indef.PL

$\begin{array}{lll}\text { duhe- } t & t \ddot{e} & e c \ddot{e} \\ \text { must-REFL.3SG } & \text { AGR } & \text { go-ConJ.Prs.3SG }\end{array}$

'Now s/he is relaxing but in a couple of minutes s/he will have to go.'

notation. Toko will be notated as 'but' in adversative meaning, elsewhere it will be kept. In all such cases, the use of these markers in examples will be specifically addressed in the text. 
(7b) Kajnas (response)

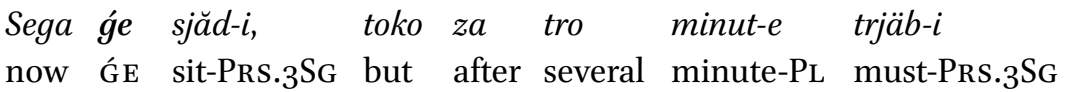

da bar-a.

AGR go-Prs.3SG

'Now s/he is relaxing but in a couple of minutes s/he will have to go.'

Obviously, there was something going on. I decided to delve deeper into how present progressive can be expressed in the dialect.

In my field study of the dialect I concentrated on this question and conducted a series of interviews with the remaining speakers. It is important to underline that Klaus Steinke and Xhelal Ylli's data was registered with the same speakers I had the chance to work with later: IK (then 74 years old) and SB (then 72), both from Boboshtica, and it was IK who drew my attention to the existence of present progressive in the dialect (see 4). However, in the data represented in Klaus Steinke and Xhelal Ylli's book he did not use any present progressive markers (probably due to the stylistic limitations). Considering this, eliciting the data I was interested in was a challenge. Translation would not work, because the speakers tended to produce ad hoc word-by-word translations from Albanian (cf. 2a), and it was methodologically impossible to tell them apart from the 'normal' Kajnas sentences. That is why I preferred using non-linguistic stimuli to make the interlocutors produce sentences. As a basis for the interview I used the picture book "Frog, where are you?" by Mercer Mayer (1969). In 24 pictures, the book depicts the adventures of a boy and a dog who are looking for their frog, and line up to a connected visual narrative. No text is offered in the book in any language. Originally a book for training children's oral skills, it has become a well-known linguistic questionnaire. For example, in 2004 there were more "than 160 projects covering a range of 72 different languages and 13 different phyla (language families)" that were based on the "frog story" (Strömqvist, vist and Verhoeven, 2004: 5). In total, I recorded six interviews with the last six speakers of the dialect in 2013-2016. The interviews lasted between 15 minutes and one hour, depending on how fluent the speaker was and how many deviations from the storyline he or she made. In the original book there were no page numbers or picture numbers. To refer to the pictures, I simply use the cardinal number of the page (the book is easy to navigate, as it has only 29 pages in total).

At the same time, I went through Mazon and Filipova-Bajrova's publications of the dialectal data (Mazon, 1936; Mazon and Filipova-Bajrova, 1956), tracing how what later become present progressive markers functioned several generations ago. 
In the course of the research, besides ge, another marker was discovered, toko. In the following I am going to first describe the use of ge, then the use of toko, and finally I am going to focus on how both markers are used by the remaining speakers of the language community.

\section{$3 \quad G$ G in Kajnas}

Ǵe goes back to the locative adverb g'e 'where' (cf. Old Church Slavonic kzde), this meaning is retained in Gospel texts from 1870s-188os and in folklore texts published by André Mazon (with various spellings: phonetic $g^{\prime} e^{16}$ and the one following Albanian orthography: gje ${ }^{17}$ ).

(8) $S e$ $\begin{array}{lllll}\text { Se } & \text { stemn- } a, & \text { fat- } i & d a & \text { ishç- } i \\ \text { REFL } & \text { get.dark-Aor.3SG } & \text { begin-Aor.3SG } & \text { Agr } & \text { look.for-Prs.3SG }\end{array}$

gje $\quad d a \quad s p-i$.

where AGR sleep-Prs.3Sg

'It became dark, he started to look for where to sleep.' (M 318) $)^{18}$

It usually has temporal meaning as a part of collocation dur ǵe ("until, before").

(9) Dur.gje ne bje rode-n-o detjë-to, before Neg be.Aor.3Sg born-PtcP-Neut child-DeF

$\begin{array}{lll}\text { zhivjë-je } & \text { mnogo } & \text { dobre. } \\ \text { live-AoR.3SG } & \text { very } & \text { well }\end{array}$

'Before he was born, they were living quite good.' $\left(\mathrm{M}_{320}\right)^{19}$

16 In Mazon's own transliterations of Gospels and transcripts of the dialectal texts.

17 In texts written by the speakers themselves.

18 French translation by Mazon: "La nuit vint: il se mit à rechercher un endroit où dormir". Here and further reference to Mazon's (1936) publication will be given as (M "page number").

19 In the usage of one of the interlocutors, EM, instead of dur ge another collocation, durvo is used, that is a calque from the respective Albanian temporal conjunction deri në (supported by the occasional phonetical similarity Alb. deri Kajnas dur; Albanian $n \ddot{e}$ 'in' is simply translated into Kajnas with $v o$ 'in'). 
I also found one case of ǵe as a connector with possible target meaning.

\begin{tabular}{|c|c|c|c|c|}
\hline $\begin{aligned} \text { (10a) toj } \\
\text { he }\end{aligned}$ & $\begin{array}{ll}\text { so } & \text { grebenec-o } \\
\text { with } & \text { crest-DEF }\end{array}$ & $\begin{array}{l}\text { skoka-j } \\
\text { jump-IMPERFECT.3Sg }\end{array}$ & $\begin{array}{l}o t \\
\text { from }\end{array}$ & $\begin{array}{l}\text { griënda } \\
\log \end{array}$ \\
\hline vo & grjënda & gje & $m^{\prime}-u b j$ & jës-e. \\
\hline in & $\log$ & AGR & I.ACC & -hang-Prs.3PL \\
\hline
\end{tabular}

Here ǵe might be considered as a locative marker if we suppose that the narrator has omitted some part.
(1ob) $[i \quad i \check{s} c ̌ c-j]$
gje da m'-ubjës-e.
and look.for-Imperfect.3Sg where Agr I.Acc-hang-Prs.3PL
'[...] [and was looking for a place $]$ where to hang me[...]'.

Many of the examples with ge that may be found in Mazon's texts can be easily explained as a locative or as a temporal marker; other meanings like that of target are quite rare and usually cannot be interpreted unambiguously.

There is another group of uses that seemed more interesting.
- IJa gj'-eje,
here where-be.Prs.3SG where cry-Prs.3SG
'And then he says, Where is the girl? - Here she is, gje cries (= is crying).' (M 334)

Mazon translates the part that interests us this way: "La voilà qui pleure", seemingly construing ǵe as a complementary connector (like Macedonian što and

\footnotetext{
20 That is how this piece was construed by Mazon as can be seen in his translation: '[...]l'animal à la crête sautait de solive en solive pour me pendre[...]'.
} 
Greek $\pi \circ v)^{21}$ and supposing that a part was omitted (*taz gje pllaçi ' the one that is crying'). But let us note that this understanding is not unambiguously grounded in the text ("Here she is, the one crying"? "Here she is, crying"?). If we take this isolated example it may seem that there is not so much to talk about: the marker is used in a not quite clear meaning but the main idea is still clear from the context. There are a couple more examples that seem to be much more definitive.

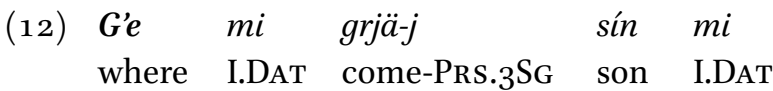

so éna nevjästa másna, so kákof

with one bride beautiful with which

müráfet da mu jo zém-a

way AGR he.DAt she.Acc take-Prs.1SG

jäskaj nevestá-ta?

I bride-DeF

'My son ǵe comes (= is coming) with a beautiful bride, how could I take the bride from him?" (M 206) $)^{22}$

21 Compare another non-definitive example from the Gospels:

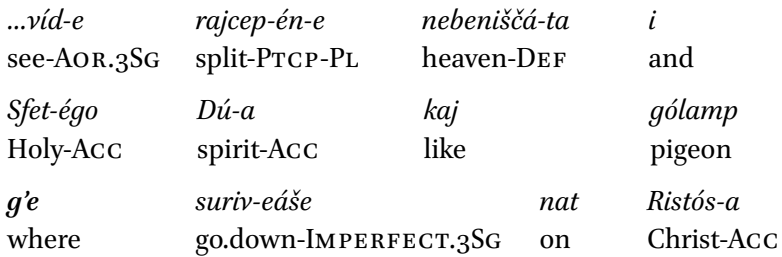

'He saw the heaven open and Holy Spirit going down like a pigeon onto Christ.' (M 121, Mk 1:10),

also

i Rístos víd-e Nathanáila g'e gred-eáše pri négo and Christ see-Aor.3Sg Nathanael where come-Imperfect.3Sg by he.ОвL ‘[...] and Christ saw Nathanel coming towards him'. (M 126, John 1:47).

Interpretation of Boboshtica Gospel translations has to be done with caution, because the original text is unknown (it should probably have been a Greek vernacular translation).

22 Mazon's translation: "Puisque voici venir mon fils avec une belle jeune femme, par quel moyen puis-je lui prendre cette femme?" 


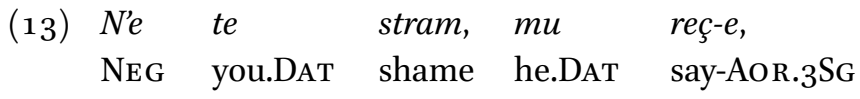

gospoin-o gje fe fal-e vo bolest,

master-Def where REFL lie-PrS.1SG in illness

esti qederos-an, a

be.Prs.3Sg sad-PTcP and

ti toko igra-sh so kokoshqjë-te?

you Toko play-Prs.2Sg with hen.PL-DEF

"Shame on you, he said, our master gje is ill and sad and you are just strutting around with the hens?" (M 296) ${ }^{23}$

There is one more example in the Gospel translations.

$\begin{array}{llll}\text { (14) } R a d v \text {-ej-té } & \text { se } & \text { na toj den, } \\ \text { rejoice-IMP-2PL } & \text { REFL } & \text { on that day }\end{array}$

i igrá-j-te óti já g'e vi vél'-a

and play-IMP-2PL because I where you.DAt.PL say-Prs.1SG

áko váš bánd-i mnógo vo nebeniščá-ta"

if your be-Prs.3Sg a.lot in heaven-DeF

'Rejoice in that day and play, becase I am telling you that you will have a lot in heaven.' (M 121, Lc 6:23)

In the personal letters, one example of progressive was found.

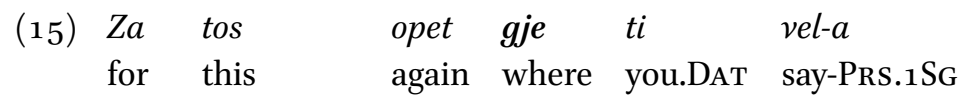

da sië-sh reat $i$ da ië-sh para mnogo.

Agr sit-Prs.2Sg relax and Agr eat-Prs.2Sg money.PL a.lot

'That is why I gje tell (= am telling) you one more time, calm down and don't cut your spending for eating.' (Mazon, Bajrova 1965: 7o) ${ }^{24}$

23 Mazon's translation: "N'as-tu pas honte, lui dit-il, alors que le maître tombe malade et a du chagrin, de ne faire que jouer avec tes poules?"

24 Mazon's translation: “C'est pourquoi, je te le dis encore, reste là tranquille, et mange bien.” 
For ge in these sentences (14-15) none of the meanings is suitable: neither locative, nor temporal, nor complementary connector, but the sentence does make perfect sense if we construe ǵe as a progressive marker.

$G$ Ge as a progressive marker in Mazon's publications is very rare - in more than 140 pages of text there are only four examples. Cases where one would expect its use to denote the progressive aspect of an action are everywhere in Mazon's data, but they usually lack any specific progressive markers. Compare the use of numerous performatives in the letters: te baçva 'I'm kissing you,', 25 ti se mola 'I'm begging you', that do not differ as to progressivity from the abovementioned za tos opet gje ti vela ("that is why I ge tell (= I am telling) you").

Due to the scarcity of sources for the earlier stages, the path of diachronic semantic development of ge into a progressive marker is not very clear. The starting point of this process is locative ( $g$ e 'where'), which is also typologically frequent. The fact that it matches the probable etymology for Albanian duke is a coincidence: the development of these two markers can hardly be connected, as the initial locative meaning of duke is by no means apparent in modern Albanian. Presumably, the structural influence of progressive po constructions also played its role.

In the interviews, ǵe was used only by IK and only twice in the 46 -minute narrative. ${ }^{26}$

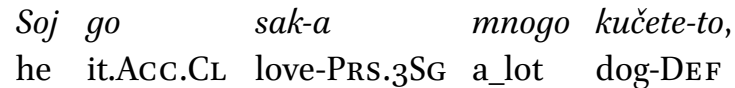

i kučete-to ǵe go bačuv-a. Ǵe go bač-i.

and dog-Def Ǵe it.Acc.Cl kiss-Prs.3Sg Ǵe it.Acc.CL kiss-Prs. 3 Sg 'He loves the dog very much, and the dog is kissing him. It is kissing him.' (after Mayer, 1969: 7).
IK: Toj ǵe gled-a
kučence-to,
gled-a
he ǴE watch-Prs. ${ }_{3}$ Pl dog.Dimin-DeF watch-Prs.3PL he
MM: $A$
kučence-to
što čin-it?
INTERROG
dog.Dimin-DeF
what
do-Prs.3SG

$\operatorname{toz}[\ldots]$

25 For example, in IK's letter to his older brother to Paris, written when IK was 9 years old (Mazon, 1956: 67): “Te baçva mnogo gorjëshço, bolif moj brat" 'Je t'embrasse très chaleureusement, mon cher frère', “Te baçva Ilo pallavuçka" 'Je t'embrasse. Ilo l'Agité'.

26 It is very rare compared to the number of times another progressive marker, toko, was used by EM, RM, VsM, and ViM, see further. 




$$
\begin{aligned}
& \text { Jas ne pul-em nebre. <...> Liži } \\
& \text { I Neg watch-Prs.1PL good lick-Prs.3SG something }
\end{aligned}
$$

'He is watching the dog, he is watching. [MM:] What is the dog doing?

[IK:] It is smelling something, or I don't know, watching. I don't see well. It is licking something' (after Mayer, 1969: 26).

IK uses it in (17) in the first sentence with the verb describing action in process, but omits it when he repeats the verb (Toj ǵe gleda kučenceto, Ø gleda toz). At the same time, in the sentence Meriši, ili ne znem, puli, with the verbs describing actions in progress as well (meriši, puli), he does not use any specific markers. He seems to have acquisited the marker (to the extent he could even compare it and match it to its Albanian counterpart, and to comment on that metalinguistically, cf. ex. 6), but he obviously treated it as supplementary. This is probably the same way it was treated in Kajnas between the 1870 s and the 1930s, as can be seen from its rare use during that period.

From what can be seen in the earlier texts in Kajnas and in IK's use, ǵe is a marker that corresponds to Albanian progressive $p o$. Its use to express progressivity in Kajnas in the 1930s was not yet stabilized, and it was used optionally. I would describe this process as grammaticalization that was stopped due to extralinguistic reasons - the community of speakers shrank drastically and IK was the only one of the last remaining speakers to use progressive ge the way it is attested in texts registered by Mazon.

\section{Toko in Kajnas}

Another marker for progressive I discovered in the interviews was toko. Toko 'en train de, mais' together with tétka 'si tellement' date back to *toliko (Mazon, 1936: 43-44). Toko is more frequent than ǵe in progressive constructions in the texts published by Mazon, who even included it into his dictionary with progressive as first meaning (adversative second).

“tóko, en train de [...]; mais; tóko réči presque, environ; tóko ščo, à peine un acte s'est-il produit que [...]" (Mazon, 1936: 446)

He comments on it elsewhere (Ibid.: 81), treating it as a temporal adverb and saying it introduces an aspectual constraint: only imperfective verbs are 
allowed in the scope of toko. If all the collocations (toko ščo 'in the process of', toko reči 'almost', tóko ščo 'as soon as') are left aside, two meanings remain: the progressive one and toko as an adversative marker. These can be differentiated positionally, as progressive toko has only a verb (not a VP) in its scope, while adversative toko operates on the sentence level (e.g., 18 vs. 19). This is also implied by the fact that toko cannot be separated from the verb (only clitics can be placed between them, see 20). Another limitation is that progressive toko can only have an imperfective verb in the present (19 - in fact, historical present) or past (20, 21 - imperfect, never aorist).

(18) Jed-oje,

pij-e,

$m u$

zaved-oje $\quad i$

eat-ImPenfect.3Pl drink-ImPerfect.3Pl him.Dat.Cl bring-Aor.3PL and

tomu, [toko $\left[\begin{array}{lll}\text { toj } & n^{\prime}-i & \text { upit-a }\end{array}\right.$

him.DAt toko he NeG-them.Acc.CL ask-Aor.3SG

ot

shç'-ima-te]].

Comp what-have-Prs.2PL

'They ate, drank, brought to him, but he didn't ask what they had.'

(M 340)

(19) Stana-je ludi-ti pobenja-je $i$ toj

stood_up-Aor.3PL people-Def ran-Aor.3PL and he

[toko [se um-i $]$ : $\quad$ shço sebep

токо ReFL think-Prs.3Sg what thing

$z h a^{\prime}-j e$.

Fut-be.Prs.3SG

'The people stood up, ran, and he is thinking: what's this thing?'

(M 340)

(20) Car-o toko go činjä-je azar

king-Def токо him.Acc.CL make-IMPenfect.3PL preparation

da go ubjäs-e.

Agr him.Acc.CL hang-Prs.3PL

'They were preparing the king for hanging.' (M 204) 


\begin{tabular}{|c|c|c|c|c|}
\hline$(21)$ & $\begin{array}{l}\text { Mum }{ }^{\mathrm{j}} \ddot{a}-t e \\
\text { girl.PL-DEF }\end{array}$ & $\begin{array}{l}n e ́ \\
\text { NEG }\end{array}$ & $\begin{array}{l}\text { go } \\
\text { him.ACC.CL }\end{array}$ & $\begin{array}{l}\text { pribrá-je, } \\
\text { took-AoR.3PL }\end{array}$ \\
\hline & starč̀ä-to & toko & ptač-jääše. & \\
\hline & old_man-DEF & токо & cried-IMPERFECT.3SG & \\
\hline
\end{tabular}

In total there are 29 cases of progressive toko in Mazon's publication (1936): none in the Gospel translations (only ǵe was used in the Gospels), and none in the letters. From these 29 cases, 16 are present progressive ${ }^{27}$ - in direct speech of the characters and historical present (as in 11), and 13 cases are imperfect progressive (as in examples 20 and 21 ). ${ }^{28}$ At the same time, in many examples of actions in progress we do not find toko.

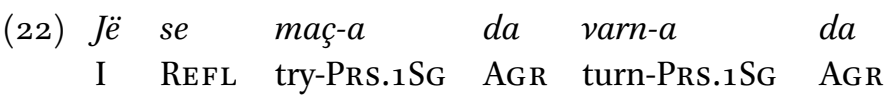

$\begin{array}{lllll}\text { zaved-a } & \text { reka-ta } & \text { nagore } & \text { d'-ima-me } & d a \\ \text { bring-PRS.1SG } & \text { river-DEF } & \text { upwards } & \text { AGR-have-PRS.1PL } & \text { AGR }\end{array}$

pijë-me.

drink-Prs.1PL

'I am trying to turn the river upwards so that we have [something] to drink.' (M 192)

Considering the optional use of toko in Mazon's publication, it might be superfluous to speak about the constraints on it, but some very rough observations can be made. Progressive toko does not have the following in its scope: 'to be' and 'to have', 'private' states (states of mind, volition, attitude - Quirk et al., 1989: 202), modals, or verbs of desire. It is not applied to qualities and states but only to events that have limited duration and are not complete, which makes it

27 Here are the numbers of pages after (Mazon, 1936) with the numbers of lines (the Gospels and tales published in Mazon 1936 have line numbering starting anew for each text): 230 : 30; 250: 44; 280: 55; 280: 62; 296: 31; 300: 51; 306: 15; 314: 3 (three times); 320: 40; 334: 57; 340: 10; 342: 16; 348: 96 ; 368: 10 .

28 See Mazon (1936): 188: 9; 188: 28; 204: 40; 218: 1; 220: 37; 236: 1; 274: 1; 278: 13; 278: 24; 280: 78; 298: 41; 316: 17; 368: no number. 
progressive sensu stricto. No cases of habitual progressive ('The professor is typing his own letters while his secretary is ill'; Quirk et al., 1989: 199) were found.

As previously mentioned, there were no cases of progressive toko (or ǵe) in Steinke and Ylli (2007), most probably due to the limited stylistic range of the narratives published there. The very regular use of progressive toko in most of the interviews I conducted with the last speakers of the dialect in 2013-2016 was unexpected. Out of the six speakers in total, only one (IK) seems to not use progressive toko at all, but he uses ge instead, see above. Another speaker, SB, uses progressive toko only once. Occasionally, exactly these two speakers make up most of Klaus Steinke and Xhelal Ylli's data from Boboshtica. ${ }^{29}$

The other four speakers, RM, VsM, and ViM (all siblings, from Drenova, living currently in Korça), and EM (in Boboshtica) used progressive toko quite often: RM 50 times, EM 61 times, VsM 33 times, ViM $5^{2}$ times, for the visual story that has only 24 pictures. As an illustration I would like to show a part of the interview I conducted with RM (after Mayer, 1969: 12-13). ${ }^{30}$

(23) RM: Detjeto ima vlezjeno tua. Toko vidi (1) ena dupka goljema, 'The boy has entered here. He toko looks (= is looking) (1) at a big hole.

am šcó ima vnátri jé ne púlem (2) nješč. Toko se darži (3) toj but what's inside I don't see (2) anything. He toko holds (= is holding) himself (3)

so racjete, i nodzjete ima (4) tua saz ljevata... saz pravata, with his hands, and he has (4) his legs here, here's the left one, here's the right one, saz ljevata. Ima panato saz so pcélite, da velime. here's the left one. This one with the bees fell down, so to say. Kučeto toko bjega (5).

The dog toko runs (= is running) (5).'

MM: Toko bega?

'Toko runs (= is running)?'

RM: M-m, toko je vidi (6). Tóko... isplášen se (7), se vidi (8).

29 The third speaker in their data, KK, had only three sentences with no examples of progressive marking. By the time I was conducting interviews, he had unfortunately passed away.

30 I highlight toko in the speech of the informant (but not in my questions). Since in this example I am rather interested in the way toko functions on the text level, I will allow myself to not provide the full grammatical notation. 
'Mhm, it toko watches (= is watching) (6) it. It is... it is (7) afraid, apparently (= as I see it) (8).

Daléku eje (9) sez, ne... Može ( 10 ) da go íma servano soj.

They are (9) far, no... He might (10) have made it fall down.

I ima panato dolu. Siez panaje i ižljezoje.

So it has fallen down. These fell down and came out.

I uplášene ese (1 1 ) i sjez. Soj glušec n'eje (12) glušec. Ščo ése (13)?

They are (11) afraid as well. This mouse is not (12) a mouse.

What is (13) it?

Ne go znjem (14) imjeto jes.

I don't know (14) its name.'

MM: Nješ drugo.

'Something different.'

RM: Nješ drugo ža je. Ne znem (15) imjeto.

'Should be something different. I don't know (15) its name.'

In (23) toko is applied to the actions in progress, synchronic to the moment of speech $(23: 1,3,5,6)$. The verbs 'to be' $(23: 7,9,11,12,13$, however, see further discussion after examples 24-25) and 'to have' (23:4), as well as modals (23:10) and 'private' states (23: 14-15) do not have toko. Morphosyntactic constraints for toko in the interviews are apparently the same as in Mazon's publication (scope over an imperfective verb in present or imperfect past, separable only by clitics), and they help distinguish it from adversative toko in the same way as described above for Mazon's publication (cf. 23: 1 vs. 23: 7).

An interesting contrast can be seen between verbs of perception that belong to the narrative (23: 1 detjeto[...] toko vidi ena dupka ('the boy[...] toko looks (=is looking)'); 23: 6 Kučeto[...] toko je vidi ('the $\operatorname{dog}[. .$.$] toko watches$ (= is watching) ')), and to the comments by the narrator (23: 2 šč ima vnatrije ne pulem ('what's inside I don't see'); $23: 8$ isplašen se, se vidi ('it is (7) afraid, apparently (= as I see it ') )). ${ }^{31}$ The events of the narrative and the autocommentary of the narrator seem to be synchronic: the narrator is watching the picture and is describing what he sees as if it were occurring at exactly the same time. However, the narrator differentiates between the layer of the narration and reality, and that is signalled by presence or absence of progressive toko, so that it thus can be interpreted as a deictic element.

31 The opposition between vidi 'see', puli 'look', and gljända 'watch' seems to be lost in the dialect, probably after colloquial Albanian merger of shikoj 'see' and shoh 'look, watch' (both verbs are used as synonyms in Standard Albanian). 
Note also that even in quite long fragments of narrative describing ongoing actions and their settings, the verbs for actions are quite rare. Segment (23), for example, is an almost a two-minute fragment with fifteen verbs in present tense (and four more perfects), and here we find only four progressive forms: other verbs are either 'to be', modals, or signal autocommentaries. There are also general truth statements in other examples, "These are bees. Bees do that and that $[. .$.$] ", that do not require progressive.$

An important change that seems to have occurred in Kajnas since Mazon's description in the 1930s is that it is now permitted to use at least the verb 'to be' in the scope of progressive toko. ${ }^{32}$

$\begin{array}{lll}\mathrm{RM}: \text { Kuče-to toko eje } & \text { vo voda } \\ \text { dog-DeF } & \text { TOKo is.PRs.3SG in water } \\ \text { 'The dog is ("is being") in the water.' (after Mayer, 1969, picture 24) }\end{array}$

(25) MM: I šo stana?

'So what happened?'33

$\begin{array}{ll}\text { ViM: } & \text { Toko jesti tua detje-to } \\ & \text { токо be.Prs.3SG here boy-DeF } \\ & \text { 'The boy is ("is being") here.' (after Mayer, 1969: 23) }\end{array}$

Obviously this method of data elicitation has certain limits. One of them is that my interlocutors tend to use present instead of the past when describing the pictures in the frog story (only one case of progressive imperfect was found in my data). However, the frog story gives a good example of moving reference at least in present. Static pictures are combined to create a storyline, and each

32 Among many of the topics the data on Boboshtica-Kajnas dialect raise is the huge variation at the intra-speaker as well as the inter-speaker level that is emerging due to various effects (Palosaarri and Campbell, 2011): imperfect language acquisition, overgeneralizations, mergers etc. The use of ${ }_{3} \mathrm{Pl}$ instead of ${ }_{3} \mathrm{Sg}$ for 'to be' (ese instead of eje or esti by RM) is definitely an overgeneralization through transfer from another part of the paradigm, while the use of only one variant of $3 \mathrm{Sg}$ for 'to be' (eje instead of esti by RM; esti instead of eje by EM) is an overgeneralization of one of the concurring variants.

33 Possible homonymy between progressive and adversative toko (grammatical criteria as scope, inseparability, and aspect of the verb cannot be applied here) can be eliminated if the broader context is taken into account. This is a start of the comment on another picture, and the narrator is lacking not just a main sentence, but also a general context to which this clause could be contrasted. 
picture depicts several momentary actions in progress. At the very beginning of the story the speakers prefer to give static descriptions 'This is a room. This is a boy. The boy is in the bed.', but usually from the second picture already they tend to use progressive in their description, as the action starts to progress. ${ }^{34}$ (after Mayer, 1969:2)

(26a) RM: A-a-a, tua toko spje, detjéto so kučéto.

'Here they toko sleep (= are sleeping), the boy and the dog.'

(26b) EM: Detjeto toko spie so kučeniščéto. Túa ése čizmjéte.

The boy toko sleeps (= is sleeping) with the dog. These are the boots.'

(26c) MM: Tuka šo stana?

'What happened here?'

VsM: Toko spi, po fle, malečko toko spi!

'He toko sleeps (= is sleeping), [in Albanian:] he is sleeping, [in Kajnas:] the little one toko sleeps (= is sleeping).'

(26d) MM: Dobre, tuka?

'Ok, here?'

ViM: Tua toko spi saz. Vo krevatka. ${ }^{35}$

'Here she toko sleeps (= is sleeping). In a bed.'

(26e) MM: Toa e posle.

'This happens later.'

SB: Tua toko spie obata vo krevatot.

'Here both of them toko sleep (= are sleeping) in bed.'36

34 As in (23), no grammatical notation is provided.

35 Note the reverse borrowing of suffix $-k$. Originally a Slavic female diminutive suffix, it was borrowed by Albanian Korça dialect where it became compatible with nouns of both Albanian genders (male and female), cf. following pairs (first member of the pair is Albanian Standard, the second member Albanian Korça dialectal): djalë 'boy, guy' - djalkë ('boy, guy', diminutive); greke 'Greek woman' - greçkë, and to a large extent started losing its diminutiveness, cf. hithër 'nettle (Urtica)' - ithkë, harabel 'sparrow' - rabeckë.

36 One cannot ignore the huge irregularity of forms in the last speakers' usage that are the result of various independent generalizations (cf. 3 Sg: EM spie, ViM, VsM spi; $3 \mathrm{Pl} \mathrm{RM} \mathrm{spje,}$ SB spie). 
The speakers seem to match progressive toko and Albanian progressive po: apart from mere mutual translatability, there are also cases of code-switching around toko or po. In example (27), the speaker switches to Albanian after the pause. In (28), the speaker in the flow of Kajnas speech switches to Albanian, inserts Albanian $p o$, but then he probably realizes that he is supposed to talk Kajnas and switches back. In (29) the speaker uses Albanian progressive po, but puts the Kajnas verb pule 'watch' in its scope.

(27) ViM: Sega toko go[...]ll po $\quad$ pe kërko-n. now токо him.Acc.Cl Prog him.Acc.CL look_for-Prs.3Sg 'Now he is looking for him.' (after Mayer, 1969:4)

(28) RM: I go krenv-i, $i$ po, po, viči. and him.Acc.CL rise.up.Prs.3Sg and Prog Prog cry-Prs.3Sg 'And he rises him up, and he is, he is crying.' (after Mayer, 1969:4) ) $^{37}$

(29) VsM: Po

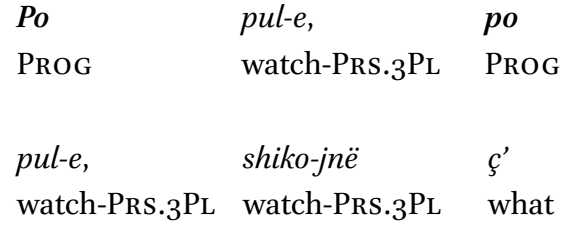

bë-het.

happen-Prs.REFL.3SG

'They are watching, they are watching what is going on.' (after Mayer, 1969: 28-29)

This means that, structurally, the speakers match progressive constructions to their Albanian counterparts. This is supported by the structural similarity: both progressive markers operate on a finite verb, both markers are "simple, unbound, syllabic" in the sense of O'Shannesy (2011: 88), which facilitates their

37 The examples with partial realizations of elements should be taken into consideration with caution. An anonymous reviewer suggested that this example can also be interpreted as asseverative ("And he raises him up and yes he is crying"). There is nothing to support or to disprove one reading before the other, although this contextual polysemy, as the reviewer suggests, is similar to what might have given rise to Standard Albanian $p o$ 'yes'. Luckily, this is not the only example proving that po and toko are mapped to each other, see 19 and 21. 
structural match between Albanian and Kajnas in modern usage. The match is also supported by the similar homonymy: both $p o$ and toko have progressive and adversative meanings.

At the same time, the phonetic form of toko seems to correspond to another Albanian progressive marker, duke, though toko does not follow its structural pattern (finite verb in its scope instead of gerund) and definitely has broader semantics, matching rather that of po ("momentary action in progress" instead of mere "Gleichsetzung").

The possible process of grammaticalization of toko in Kajnas seems to have combined influences from both Albanian progressive markers: adversative meaning provided the match with $p o$, while phonetic similarity to duke supported the transfer of meaning. While in Mazon's data from 1870-188os the progressive toko is not registered at all, and in the 1930s toko seems optional, in my interviews conducted in 2013-2016 it is already almost omnipresent and as has been shown, can attach even to 'to be' (impossible for Albanian po). Albanian-Kajnas bilingualism with Albanian as first language seems to have supported the grammaticalization of toko that has been identified with $p o$, and then it sometimes seems to be mechanically put everywhere where po would have been expected in Albanian. It can be seen in (30) (after Mayer, 1969: 8-9), where the speaker mistakenly maps po to Kajnas $a k o$ 'if', perhaps following the use of $p o$ in Albanian conditional constructions.

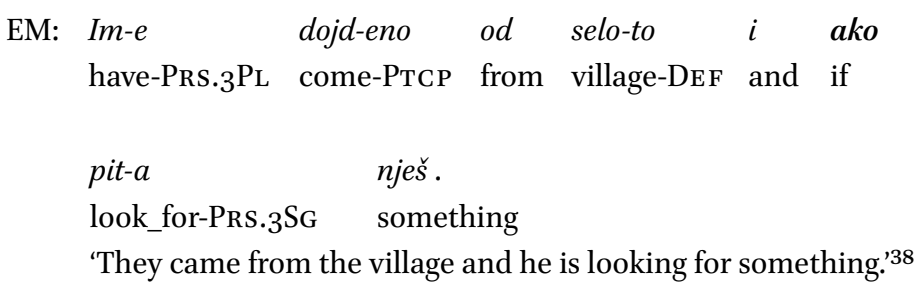

\section{Conclusion}

To sum up, the situation with progressive markers in Kajnas seems to be as follows. While in genetically-related languages (Slavic) there is no grammaticalized progressive marking (unless under strong external influence, as in Slovincian), Kajnas has developed two markers of this kind. Both of them are simple, unbound, and syllabic, and have finite verb forms in their scope

38 Cf. also the false use of pita 'il demande, il mendie' instead of iti 'il veut, il aime' or išči 'il recherche, il désire, il veut', probably under the influence of Albanian kërkoj 'to seek' but also 'to ask for, to demand'. 
(present or past imperfect). Both of them seem to structurally follow the Albanian progressive po constructions. While ǵe remained peripheral and facultative from the very first registered cases until the death of the last speaker who used it, toko seems to have moved forward along the grammaticalization path. The increasing Albanian influence (structurally, from po constructions; on the phonetic level, from duke) and continuous language attrition in the background supported the increase of obligatoriness of toko. It should be underlined that for the stage of the first appearance of the progressive markers in the texts, we cannot speak about imperfect acquisition or language attrition of the dialect. In the 1930s, it is still a vivid language variety that is used in various styles as well as in informal family communication, and at the same time it already uses the aforementioned markers in various functions, progressive among them. The process of language attrition that can be inferred on the basis of the interviews I have conducted, seems to have played a special role in the way how the semantics and use of ge and toko changed over the last 80 years.

The uneven use of these markers by different members of the Kajnas language community in 2013-2016 demonstrates various issues connected to language shrinkage. Of the six (presumably) last speakers I have interviewed, four have acquired progressive toko that seems to be very regular in their speech. One (SB) has partly acquired it, he also happens to be the least fluent speaker. One speaker (IK) seems to have not acquired it at all (or suppressed it under the influence of related Czech that seems to have strongly influenced his production and/or performance on the structural level, (see Makartsev, 2013a; Makartsev, 2013b), but he used ge, that was unknown to all the other speakers. (I consciously do not use the term "speech community", as in normal conditions my interlocutors do not speak Kajnas to each other)

On the basis of the existing data from the previous stages of the dialect, I come to the conclusion that with the continuous loss of speakers, two markers that for some period of time coexisted in Kajnas were, due to imperfect acquisition, inherited by now separate parts of the language community. Of these two markers, ǵe was used only as an optional progressive marker. The grammaticalization of toko was supported by the phonetic similarity to Albanian duke and structural identification to $p o$.

\section{Interlocutors}

EM, female, 1936-2020, born in Boboshtica, graduated from a pedagogical college as a teacher of Albanian in elementary school. Lived in Boboshtica. Recorded on 15 September 2013. 
IK, male, 1925-2016, born in Boboshtica, graduated as an engineer from Charles University in Prague. Lived in Boboshtica. Recorded on 19 September 2014.

MM [researcher], male, born in 1984 in Moscow.

$\mathrm{RM},{ }^{39}$ male, born in 1934 in Drenova, graduated from Tirana University as a teacher of science. Lives in Korça. Recorded on 14 September 2013.

SB, male, born in 1929 in Boboshtica, graduated from a pedagogical college as a school teacher of mathematics. Lives in Boboshtica. Recorded on 25 July 2016.

ViM, ${ }^{39}$ female, born in 1927 in Drenova. Lives in Korça. Recorded on 24-25 July 2016.

VsM, ${ }^{39}$ male, born in 1922 in Drenova. Lives in Korça. Recorded on 03 September 2016.

\section{Abbreviations}

1-3 - first, second, third person; ABL - ablative; ACC - accusative; ADV PTCP - adverbial participle; AG R - agreement; AoR - aorist; CL - clitic; COM P complementizer; CONJ - conjunctive; DAT - dative; Dim IN - diminutive; DAT - dative; DE F - definite; DIM IN - diminutive; FUT - future; IMP ER FECT imperfect tense; INDEF - indefinite; INTE R ROG - interrogative; NE G - negative; PL - plural; PrS - present; PTCP - participle; REFL - reflexive; SG - singular.

\section{Acknowledgement}

I am grateful to Anastasia Makarova (University of Zurich) for the help with the map.

\section{References}

ADGJSh: Atlasi dialektologjik i gjuhës shqipe. Bahri Beci, Gjovalin Shkurtaj, Xheladin Gosturani; Bashkëpunuan Anastas Dodi, Menella Totoni; Drejt. Jorgji Gjinari. Vëll. 1-2. Napoli: Università degli Studi di Napoli L'Orientale; Dipartimento di Studi dell'Europa Orientale, 2007-2008. 
ANC: Albanian national corpus. Marija Morozova, Marija Domosiletskaya, Aleksandr Rusakov, Ekaterina Bernatskaya, Anastasija Sidko, and Anna Konovalenko. Moscow-Saint Petersburg: ILI RAN, 2011-. (http://web-corpora.net/AlbanianCorpus/ search/ Accessed 17 July 2018).

Brown, Christopher and Joseph, Brian D. 2015. On hybrid forms in language contact: Some evidence from the Greek of Southern Albania. In Albanohellenica 6: 49-57. (Proceedings of the 2nd International Conference of Greek-Albanian / AlbanianGreek Studies (ICGAS II, Tirana, March 27th-28th, 2015)).

Buchholz, Oda and Fielder, Winfried. 1987. Albanische Grammatik. Leipzig: Verlag Enzyklopädie.

Bybee, Joan, Perkins, Revere, and Pagliuca, William. 1994. The Evolution of Grammar: Tense, Aspect, and Modality in the Languages of the World. Chicago: University of Chicago Press.

Clyne, Michael G. 2003. The Dynamics of Language Contact. Cambridge: Cambridge UP.

Comrie, Bernard. 1998/1976. Aspect. An Introduction to the Study of Verbal Aspect and Related Problems. Cambridge: Cambridge.

Hentschel, Gerd and Zeller, Jan Partick. 2013. Gemischte Rede, gemischter Diskurs, Sprechertypen: Weißrussisch, Russisch und gemischte Rede in der Kommunikation weißrussischer Familien. Wiener Slawistischer Almanach 70: 127-155.

Joseph, Brian. 2011. The puzzle of Albanian po. In Eirik Welo (ed.), Indo-European syntax and pragmatics: contrastive approaches, 27-40. Oslo: University of Oslo. (Oslo Studies in Language 3(3)).

Mair, Christian. 2012. Progressive and continuous aspect. In Binnick, Robert I. (ed.). The Oxford Handbook of Tense and Aspect. New York: Oxford UP. P. 803-827.

Makartsev, Maxim M. 2013a. Innovacii v glagol'noj sisteme slavjanskogo govora Bobošticy (obl. Korči, Albanija). In Moldovan, Aleksandr M., and Svetlana M. Tolstaja. (eds), Slavjanskoe jazykoznanie. XV meždunarodnyj sjezd slavistov, Minsk, 21-27 avgusta 2013 g. Doklady rossijskoj delegacii. Moskva: Indrik. S. 512-534.

Makartsev, Maxim. 2013b. Gramatička interferencija vo dijalektot na Boboštica: kon tipologijata na slovenskoto i neslovenskoto vlijanie. In XXXIX naučna konferencija na XLV meǵunaroden seminar za makedonski jazik, literatura i kultura. Lingvistika. Ohrid, 20-21 juni 2012 g. Skopje: Univerzitet “Sv. Kiril i Metodij”. S. 29-41.

Makartsev, Maxim M. 2017. Identičnost' i vlast, performans i praktika v polevom issledovanii. K izučeniju balkanoslavjanskix idiomov v neslavjanskom okruženii. Galina P. Neščimenko (red.). Aktual'nye ètnojazykovye i ètnokul'turnye problemy sovremennosti. Étnokulturnaja i ètnojazykovaja situacija - jazykovoj menedžment jazykovaja politika. Moskva: "Jazyki slavjanskoj kul'tury”. S. 261-294.

Matras, Yaron. 2009. Language Contact. New York: Cambridge UP. 
Matzinger, Joachim. 2006. Der altalbanische Text Mbsuame e Krështerë (Dottrina cristiana) des Lekë Matrënga von 1592. Eine Einfürung in die albanische Sprachwissenschaft. Dettelbach: Verlag J. H. Röll GmbH. (Jenaer indogermanistische Textbearbeitung, hrsg. von Rosemarie Lühr und Susanne Zeilfelder; Band 3)

Mayer, Mercer. 1969. Frog, where are you? Sequel to A boy, a dog and a frog. New York: Dial Books for Young Readers (a division of Penguin Putnam Inc.).

Mazon, André. 1936. Documents, contes et chansons slaves de l'Albanie du Sud. Paris: Librairie Droz. (Bibliothèque d'études balkaniques - v.)

Mazon, André and Filipova-Bajrova, Maria. 1965. Documents slaves de l'Albanie du Sud. II. Pièces complémentaires. Paris. (Bibliothèque d'études Balkaniques - VIII.)

Morozova, Marija S., Arxangel'skij Timofej A., Danièl', Mixail A., Rusakov, Aleksandr Ju. 2016. Albanskij nacional'nyj korpus: osnovnye napravlenija raboty. In Nikolaj N. Kazansky (ed.). Acta linguistica Petropolitana. Transactions of the Institute for Linguistic Studies. Vol. xii, part 3, 169-19o. St. Petersburg: Nauka.

Muysken, Pieter. 2013. Language contact outcomes as the result of bilingual optimization strategies. Bilingualism: Language and Cognition 16(4): 709-730.

Newmark, Leonard, Philip Hubbard and Peter Prifti. 1982. Standard Albanian: A Reference Grammar for Students. Stanford: Stanford University Press.

O'Shanessy, Carmel. 2011. Language contact and change in endangered languages. In Peter Austin and Julia Sallaban. (eds.), The Cambridge Handbook of Endangered Languages, 78-99. Cambridge: Cambridge UP.

Orel, Vladimir. 1998. Albanian etymological dictionary. Brill: Leiden, Boston, Köln.

Palosaari, Naomi and Campbell, Lyle. 2011. Structural aspects of language endangerment. In Peter Austin and Julia Sallabank (eds.), The Cambridge Handbook of Endangered Languages, 100-119. Cambridge: Cambridge UP.

Piotrowski, Jan. 1981. Składnia słowińska wobec wplywów jezyka niemieckiego. Wrocław. Seria A. Nr. 223.

Seliščev, Afanasij M. 1931/1981. Slavjanskoe naselenie v Albanii. Sofija: Makedonski naučen institut, 1931. (reprint: Sofia: Nauka i izkustvo, 1981).

Sobolev, Andrej N. 2011. Antibalkanizmy. Južnoslovenski filolog LXVII. 185-195.

Sobolev, Andrej N. 2018. Hybrid grammar in a Macedonian dialect from Albania. In Kazansky Nikolai N. (ed.), Indo-European linguistics and classical philology. XXII. 1248-1255. (Proceedings of the 22th Conference in Memory of Professor Joseph M. Tronsky, June 18-20, 2018.) DOI: 10.30842/ielcp230690152291.

Steinke, Klaus and Ylli, Xhelal. 2007. Die Slavischen Minderheiten in Albanien (s MA). Teil 1. Prespa - Vërnik - Boboshtica. Münich.

Strömqvist, Sven and Ludo Verhoeven. (eds.). 2004. Relating events in narrative. Volume 2: Typological and contextual perspectives. Lawrence Erlbaum Associates, Inc.: Mahwah, NJ; London. 
Švedova Natalija Ju. (ed.). 1980. Russkaja grammatika. Tom I. Fonetika. Fonologija. Udarenie. Intonacija. Slovoobrazovanie. Morfologija. Moskva: Nauka.

Thomason, Sarah 2015. Endangered Languages: An Introduction. Cambridge: Cambridge UP. (Cambridge Textbooks in Linguistics).

Vidoeski, Božidar. 1997. Dijalektite na makedonskiot jazik. Tom 1. Skopje: MANU; Fond Trifun Kostovski.

Quirk, Randolph, Greenbaum, Sidney and Leech, Geoffrey. 1989. A Comprehensive Grammar of the English Language (7 ed.). London: Longman. 